\title{
Association of Chest X-Rays Features with the Length of Stay in Suspected COVID-19 Status
}

\author{
Zulmansyah, ${ }^{1,2}$ Gaga Irawan Nugraha, ${ }^{3}$ Dwi Agustian, ${ }^{4}$ Dida Akhmad Gurnida ${ }^{5}$ \\ ${ }^{1}$ Doctoral Study Program of Medical Sciences, Faculty of Medicine, Universitas Padjadjaran, Bandung, Indonesia, \\ ${ }^{2}$ Department of Child Health, Faculty of Medicine, Universitas Islam Bandung, Bandung, Indonesia, \\ ${ }^{3}$ Department of Biomedical Sciences, Faculty of Medicine, Universitas Padjadjaran, Sumedang, Indonesia, \\ ${ }^{4}$ Department of Public Health, Faculty of Medicine, Universitas Padjadjaran, Sumedang, Indonesia, \\ ${ }^{5}$ Department of Child Health, Faculty of Medicine, Universitas Padjadjaran/ \\ Dr. Hasan Sadikin General Hospital, Bandung, Indonesia
}

\begin{abstract}
Coronavirus disease 2019 (COVID-19) is a new type of respiratory infection that first emerged in December 2019 in Wuhan, Hubei, China. COVID-19 is caused by a new variant of virus called severe acute respiratory syndrome coronavirus 2 (SARS-CoV-2). Examining the chest $\mathrm{x}$-rays is one technique to diagnose COVID-19. This study aims to determine the association of chest X-rays features in suspected COVID-19 patients with the length of stay at Al-Ihsan Regional General Hospital West Java Province and Banten Regional General Hospital in June-November 2020. The subject was 29 COVID-19 people were confirmed, whereas 31 people were not. The statistical analysis used Pearson correlation and multi-linear regression. This study found that tuberculosis had a strong association with length of stay ( $p$ value $=0.048$, association $=0.4$ ), and also there is a robust association between bilateral pneumonia and duration of stay ( $\mathrm{p}$ value $=0.028$, association $=0.873$ ). A linear regression model discovery of $\mathrm{TB}$ chest $\mathrm{x}$-rays on the subject raises the treatment by 0.5867 days. In addition, the discovery of bilateral pneumonia increases the length of stay of treatment by 0.32218 days more than the discovery of unilateral pneumonia. In general, tuberculosis, bacterial pneumonia, viral pneumonia, and bilateral pneumonia together affected the outcome of length of stay of patients with suspected COVID-19.
\end{abstract}

Keywords: Chest x-rays, COVID-19, diagnosis of COVID-19, length of stay

\section{Asosiasi Gambaran Rontgen Toraks terhadap Lama Rawat pada Pasien Suspek COVID-19}

\begin{abstract}
Abstrak
Coronavirus disease 2019 (COVID-19) adalah jenis infeksi saluran pernapasan baru yang pertama kali mewabah pada Desember 2019 di Wuhan, Hubei, Cina. COVID-19 disebabkan oleh varian virus baru yang disebut severe acute respiratory syndrome coronavirus 2 (SARS-CoV-2). Pemeriksaan rontgen toraks merupakan salah satu teknik mendiagnosis COVID-19. Penelitian ini bertujuan mengetahui asosiasi gambaran rontgen toraks pada pasien suspek COVID-19 dengan lama rawat inap di RSUD Al-Ihsan Provinsi Jawa Barat dan RSUD Banten pada Juni-November 2020. Subjek penelitian adalah 29 orang terkonfirmasi COVID-19 dan 31 orang tidak. Analisis statistik menggunakan korelasi Pearson dan regresi multilinier. Penelitian ini menemukan bahwa tuberkulosis memiliki hubungan yang kuat dengan lama perawatan $(\mathrm{p}=0,048$; asosiasi $=0,4)$ dan juga terdapat hubungan yang kuat antara pneumonia bilateral dan lama perawatan $(\mathrm{p}=0,028$; asosiasi $=0,873)$. Penemuan model regresi linier rontgent toraks TB pada subjek meningkatkan risiko perawatan 0,5867 hari lebih lama. Selain itu, penemuan pneumonia bilateral meningkatkan risiko perawatan 0,32218 hari lebih lama dibanding dengan penemuan pneumonia unilateral. Secara umum, tuberkulosis, pneumonia bakteri, pneumonia viral, dan pneumonia bilateral secara bersama-sama berpengaruh terhadap luaran lama rawat inap pasien suspek COVID-19.
\end{abstract}

Kata kunci: COVID-19, diagnosis COVID-19, lama rawat, rontgen toraks 


\section{Introduction}

Coronavirus disease 2019 (COVID-19) is a new variant of respiratory tract infection that first appeared in Wuhan, Hubei, China, in December 2019. COVID-19 is caused by the severe acute respiratory syndrome coronavirus 2 (SARSCoV-2), which is a novel kind of virus. COVID-19 was declared a public health emergency of international concern (PHEIC) by the World Health Organization (WHO) on January 30, 2020, and its status was later renewed to the pandemic. $^{1}$ There were $120,417,285$ cases reported until March 15, 2021, with 1,419,455 cases reported in Indonesia, resulting in 38,426 deaths. $^{2}$

Systemic symptoms (fever, malaise, weakness, headache, myalgia), respiratory symptoms (cough, runny nose, shortness of breath), or other symptoms (diarrhea, nausea, vomiting) are all used to conduct the COVID-19 test. Ground glass opacity, unilateral or bilateral lesions, and pneumonia can also be seen on chest $\mathrm{x}$-rays. ${ }^{3}$ Abnormalities in chest $\mathrm{x}$-rays are generally distributed bilaterally. The heart, lungs, respiratory tract, blood arteries, and lymph nodes are some of the common signs found in chest $\mathrm{x}$-rays. The spine and chest, including the ribs, collarbones, and the top of your spine, can also be seen in chest $x$-rays. ${ }^{4}$ The appearance of chest $\mathrm{x}$-rays that are commonly found in COVID-19 patients is diffuse or patchy asymmetric opacity such as pneumonia caused by other types of coronavirus, such as the Middle East respiratory syndrome (MERS). ${ }^{5}$

Chest $\mathrm{x}$-rays are commonly used checks to detect diseases such as COVID-19. Bilateral/ multilobular pneumonia distribution is commonly found in patients with COVID-19. Bilateral pneumonia is inflammation that can injure the lungs. Types of pneumonia can affect both the lungs and makes the tissue around the air sacs of this vital organ irritated. ${ }^{6}$ The COVID-19 pandemic effects provide significant challenges to viral pneumonia, bacterial pneumonia, and pulmonary tuberculosis (TB) control initiatives, primarily by obstructing pneumonia, bacterial pneumonia, TB diagnosis, and treatment. Because the symptoms of tuberculosis and COVID-19 are so similar, countries with a shaky diagnostic infrastructure struggle to distinguish between the two infections; this problem harms therapeutic decision-making and, as a result, in the prognosis of both diseases. ${ }^{7}$

The link between chest x-rays in COVID-19 patients has not been demonstrated to date. Nonetheless, a better understanding of the association between these causes and disease prognosis is critical in offering the proper treatment for ill patients and delaying disease development. Furthermore, these variables can help forecast the results of COVID-19 suspected and confirmed positive events. Therefore, this study aimed to correlate chest $\mathrm{x}$-rays features in suspected COVID-19 patients with the length of stay.

\section{Methods}

This research started on June to November 2020; patients were treated at Al-Ihsan Regional General Hospital West Java Province, Bandung, and Banten Regional Hospital, Banten, West Java, Indonesia with the following signs of respiratory tract infection: 1) a high fever (above $38^{\circ} \mathrm{C}$ ); 2) respiratory problems such as cough, runny nose, shortness of breath, sore throat, or confirmed positive for pneumonia. Based on a definitive clinical image, there is no other explanation. In addition, the patient may have: 1) a history of traveling or staying in an environment where COVID-19 transmission has been registered, or 2) interaction with offenders and confirmed positives.

The patient was admitted to the radiology center for $\mathrm{x}$-rays one day after admission to the hospital. The diagnosis is divided into pulmonary tuberculosis, bacterial pneumonia, viral pneumonia, and non-pneumonia findings based on x-ray findings (pleural effusion, infiltration, lesion, and others. The impacted areas are also divided into two categories: bilateral and unilateral pneumonia. The statistical analysis used Pearson correlation and multi-linear regression.

\section{Results}

This study uses data from 6o COVID-19 patients divided into two groups: 29 positive patients COVID-19 and 31 non-confirmed COVID-19 patients (Table 1).

The average age is 48 years in both groups. Male are more in confirmed COVID-19 compared to non-COVID-19 groups. The COVID-19 group was double-folded by patients with comorbidities 
Table 1 Subject Demographic

\begin{tabular}{|c|c|c|c|}
\hline \multirow[b]{2}{*}{ Variables } & \multicolumn{2}{|c|}{ Value or Number of Patients } & \multirow[b]{2}{*}{ p Value } \\
\hline & $\begin{array}{c}\text { COVID-19 (+) } \\
(n=29)\end{array}$ & $\begin{array}{c}\text { COVID-19 (-) } \\
(n=31)\end{array}$ & \\
\hline \multicolumn{4}{|l|}{ Age } \\
\hline Year \pm standard deviation & $48 \pm 10.3$ & $48.6 \pm 20.4$ & 0.880 \\
\hline Median (range) & $47(26-64)$ & $47.5(0-86)$ & \\
\hline \multicolumn{4}{|l|}{ Gender } \\
\hline Male & 21 & 15 & 0.060 \\
\hline Female & 8 & 16 & 0.060 \\
\hline \multicolumn{4}{|l|}{ Comorbidity } \\
\hline Hypertension & 7 & 4 & 0.270 \\
\hline Heart disease & 3 & 1 & 0.760 \\
\hline Diabetes mellitus & 2 & 1 & 0.530 \\
\hline \multicolumn{4}{|l|}{ Chest $\mathrm{x}$-rays } \\
\hline Bacterial pneumonia & 16 & 20 & 0.599 \\
\hline Viral pneumonia & 8 & 3 & 0.110 \\
\hline Tuberculosis & 5 & 8 & 0.350 \\
\hline Bilateral & 14 & 6 & 0.040 \\
\hline
\end{tabular}

than the COVID-19 (-) group, but the results were not significant. In comparison, chest x-ray found a significant difference between the subject of COVID-19 and COVID-19 (-) in bilateral pneumonia of 0.040 .

Having tuberculosis has a strong association with length of stay. It means it will take longer if the subject has TB in the chest X-ray. Bilateral pneumonia has a very strong level of association. It means if the subject has bilateral pneumonia, the length of stay will be longer.

According to the results for the confounding variable, the level of correlation in the age group and diabetes mellitus is very low. In addition, gender, hypertensive comorbidity, and heart disease all have low levels of association.
The results of the regression analysis (Table 4.) If TB chest $x$-ray are discovered, the length of stay is increased by 0.5867 days. The second discovery of bilateral pneumonia chest x-ray increases the length of stay by 0.32218 days more than a unilateral pneumonia chest $\mathrm{x}$-ray discovery.

\section{Discussion}

This study found a significant difference between the subject of COVID-19 and COVID-19 (-) 19 in bilateral pneumonia chest $\mathrm{x}$-rays of $\mathrm{p}=0.040$. Aside from that, there is a very strong association between bilateral pneumonia and length of stay ( $p$ value $=0.028$, association $=0,873$ ). If

Table 2 Length of Stay in COVID-19 Subgroup

\begin{tabular}{llcccc}
\hline $\begin{array}{l}\text { Dependent } \\
\text { Variable }\end{array}$ & $\begin{array}{c}\text { Independent } \\
\text { Variables }\end{array}$ & $\begin{array}{c}\text { COVID-19 } \\
(+)\end{array}$ & $\begin{array}{c}\text { COVID-19 } \\
(-)\end{array}$ & Total & p Value \\
\hline Length of stay & Bacterial pneumonia & 21 & 17 & 38 & 0.032 \\
& Viral pneumonia & 8 & 3 & 11 & 0.989 \\
& Tuberculosis & 16 & 13 & 29 & 0.048 \\
& Bilateral & 14 & 6 & 20 & 0.028 \\
& $\begin{array}{l}\text { Confounding variables } \\
\text { Comorbidity }\end{array}$ & & & & \\
& $\quad$ Hypertension & 7 & 4 & 11 & 0.012 \\
& $\quad$ Heart disease & 3 & 1 & 4 & 0.032 \\
& Diabetes mellitus & 2 & 1 & 3 & 0.038 \\
\hline
\end{tabular}


Table 3 Length of Stay Association in COVID-19 Subgroup

\begin{tabular}{llccc}
\hline $\begin{array}{l}\text { Dependent } \\
\text { Variable }\end{array}$ & $\begin{array}{c}\text { Independent } \\
\text { Variables }\end{array}$ & p Value & Association & $\begin{array}{c}\text { Level } \\
\text { Asssociation }\end{array}$ \\
\hline Length of stay & Bacterial pneumonia & 0.032 & 0.254 & Low \\
& Viral pneumonia & 0.989 & 0.005 & Very low \\
& Tuberculosis & 0.048 & 0.400 & Strong \\
& Bilateral & 0.028 & 0.873 & Very strong \\
& Confounding variables & & & \\
& Age & 0.673 & 0.058 & Very low \\
& Gender & 0.104 & 0.322 & Low \\
& Comorbidity & & & Low \\
& $\quad$ Hypertension & 0.012 & 0.207 & Low \\
& $\quad$ Heart disease & 0.032 & 0.230 & Very low \\
\hline
\end{tabular}

there is a bilateral pneumonia chest $\mathrm{x}$-rays, the length of stay will be increased by 0.32218 days. These results are following other studies; severe bilateral pneumonia can trigger the formation of scars. This condition makes the lung tissue stiff, shortness of breath, until the breath failure which results in a length of stay the patient is getting longer. There was only one necessary chest radiograph, including bilateral pneumonia observations. The positive COVID group had slightly more bilateral pneumonia anomalies on chest radiographs (50\%) than the COVIDnegative subject group (21.4\%). According to Bao et al., ${ }^{8}$ most COVID-19 patients had bilateral pneumonia manifestations of lesions, especially bilateral lower lobes. The rate of occurrence was 78.2 percent (95\% CI $=65.69-88.19) .{ }^{8}$ COVID-19 pneumonia was overwhelmingly bilateral on the chest x-ray $72.9 \%$ of the time, based on a comprehensive meta-analysis of 2,847 patients in China and Australia and a global descriptive analysis of 39 case report articles summarizing 127 patients (95\% CI $=58.6-87.1){ }^{2}$ Lomoro et al. ${ }^{9}$ studied 32 patients with COVID-19 disease and discovered bilateral lung anomalies (78.1\%). Bilateral pneumonia was the most common finding on chest radiographs..$^{10-13}$

Tuberculosis has a strong association with length of stay $(p$ value $=0.048$, association $=0.4$ ). It means it will take longer if the subject has TB in chest $\mathrm{x}$-rays. If TB thorax photographs are discovered, the length of stay is increased by 0.5867 days. TB increases the severity to COVID-19 of its symptoms. Nonetheless, certain substantial limitations of this study should be mentioned, such as its small sample size and the lack of clinical criteria to define the presence of tuberculosis. ${ }^{14}$ Another study from the Philippines confirmed TB's negative impact on COVID-19, linking the co-infection to a higher risk of morbidity and mortality. ${ }^{15}$ However, the most significant evidence of the impact of tuberculosis on COVID-19 prognosis came from a South African cohort study. Data from almost 3 million patients treated by the public health system, with or without COVID-19, were compared, accounting for the presence of other comorbidities such as TB and HIV. The findings show that patients infected with COVID-19 are more likely to die if they had a previous history of TB. ${ }^{16}$

The study outcomes show that tuberculosis

Table 4 Length of Stay Regression Results

\begin{tabular}{lcccc}
\hline Variables & Parameter Symbol & Coefficient & Standard Error & p Value \\
\hline $\begin{array}{l}\text { Constant } \\
\text { Thorax photo }\end{array}$ & $\beta_{0}$ & 5.6957 & 0.27447 & 0.0003 \\
$\quad \begin{array}{l}\text { Tuberculosis } \\
\text { Bilateral pneumonia }\end{array}$ & $\beta_{5}$ & 0.5867 & 0.0823 & $<0.00001$ \\
\hline Note: *significant if the palue $<0.05$ & $\beta_{6}$ & 0.32218 & 0.0853 & 0.0002 \\
\hline
\end{tabular}

Note: *significant if the $\mathrm{p}$ value $<0.05$ 
increases vulnerability to COVID-19 and contributes to the severity of its symptoms subgroup. Individuals who are socially vulnerable or who have comorbidities have a worse prognosis. On the other hand, there is still no information about the impact of SARS$\mathrm{CoV}-2$ on the advancement of tuberculosis. With the evidence of a possible synergism between $M$. tuberculosis and the new coronavirus, such as the severity of symptoms and co-infection sequelae, it is clear that more practical research into the TB/COVID-19 pathophysiology is required.?

\section{Conclusions}

The discovery of TB chest x-rays on the subject raises the risk of the length of treatment. In addition, the discovery of bilateral pneumonia chest $x$-rays increases the risk of the length of treatment more than the discovery of unilateral pneumonia chest $\mathrm{x}$-rays. Thus, in general, tuberculosis, bacterial pneumonia, viral pneumonia, and bilateral pneumonia together affected the outcome of length of stay of patients with suspected COVID-19.

\section{Conflict of Interest}

There is not any conflict of interest in this research.

\section{References}

1. Aviani JK, Halim D, Soeroto AY, Achmad $\mathrm{TH}$, Djuwantono T. Current views on the potentials of convalescent plasma therapy (CPT) as coronavirus disease 2019 (COVID-19) treatment: a systematic review and meta-analysis based on recent studies and previous respiratory pandemics. Rev Med Virol [Internet]. 2021 February 23 [cited 2021 June 12]. Available from: https:// doi.org/10.1002/rmv.2225.

2. Rodriguez-Morales AJ, Cardona-Ospina JA, Gutiérrez-Ocampo E, Villamizar-Peña R, Holguin-Rivera Y, Escalera-Antezana JP, et al. Clinical, laboratory and imaging features of COVID-19: a systematic review and meta-analysis. Travel Med Infect Dis. 2020;34:101623.

3. Koh J, Shah SU, Chua PEY, Gui H, Pang J. Epidemiological and clinical characteristics of cases during the early phase of COVID-19 pandemic: a systematic review and metaanalysis. Front Med. 2020;7:295.

4. Li J, Yan R, Zhai Y, Qi X, Lei J. Chest CT findings in patients with coronavirus disease 2019 (COVID-19): a comprehensive review. Diagn Interv Radiol [Internet]. 2020 November 2 [cited 2021 June 12]. Available from: https://doi.org/10.5152/ dir.2020.20212.

5. Hefeda MM. CT chest findings in patients infected with COVID-19: review of literature. Egypt J Radiol Nucl Med. 2020;51(1):239.

6. Zwart P, Samour J. The avian respiratory system and its noninfectious disorders: a review. J Exot Pet Med. 2021;37:39-50.

7. Mousquer GT, Peres A, Fiegenbaum M. Pathology of TB/COVID-19 co-infection: the phantom menace. Tuberculosis. 2021;126:102020.

8. Bao C, Liu X, Zhang H, Li Y, Liu J. Coronavirus disease 2019 (COVID-19) CT findings: a systematic review and meta-analysis. J Am Coll Radiol. 2020;17(6):701-9.

9. Lomoro P, Verde F, Zerboni F, Simonetti I, Borghi C, Fachinetti C, et al. COVID-19 pneumonia manifestations at the admission on chest ultrasound, radiographs, and CT: single-center study and comprehensive radiologic literature review. Eur J Radiol Open. 2020;7:100231.

10. Chen N, Zhou M, Dong X, Qu J, Gong F, Han $\mathrm{Y}$, et al. Epidemiological and clinical characteristics of 99 cases of 2019 novel coronavirus pneumonia in Wuhan, China: a descriptive study. Lancet. 2020;395(10223):507-13.

11. Rousan LA, Elobeid E, Karrar M, Khader Y. Chest $\mathrm{x}$-ray findings and temporal lung changes in patients with COVID-19 pneumonia. BMCPulm Med. 2020;20(1):245.

12. Cozzi D, Albanesi M, Cavigli E, Moroni $\mathrm{C}$, Bindi $\mathrm{A}$, Luvarà $\mathrm{S}$, et al. Chest X-ray in new coronavirus disease 2019 (COVID-19) infection:findings and correlation with clinical outcome. Radiol Med. 2020;125(8):730-7.

13. Vancheri SG, Savietto G, Ballati F, Maggi A, Canino C, Bortolotto C, et al. Radiographic findings in 240 patients with COVID-19 pneumonia: time-dependence after the onset of symptoms. Eur Radiol. 2020;30(11):61619.

14. Motta I, Centis R, D’Ambrosio L, GarcíaGarcía JM, Goletti D, Gualano G, et al. 
Tuberculosis, COVID-19 and migrants: preliminary analysis of deaths occurring in 69 patients from two cohorts. Pulmonology. 2020;26(4):233-40.

15. Sy KTL, Haw NJL, Uy J. Previous and active tuberculosis increases risk of death and prolongs recovery in patients with COVID-19.
Infect Dis. 2020;52(12):902-7.

16. Davies MA. HIV and risk of COVID-19 death: a population cohort study from the Western Cape Province, South Africa. medRxiv [Internet]. 2020 July 3 [cited 2021 June 12]. Available from: https://www.medrxiv.org/co ntent/10.1101/2020.07.02.20145185v2. 